Please do not remove this page

RMIT

UNIVERSITY

\title{
Studying the mobile: Locating the field
}

Hjorth, Larissa; Burgess, Jean; Richardson, Ingrid

https://researchrepository.rmit.edu.au/esploro/outputs/9921858622201341/filesAndLinks?institution=61RMIT_INST\&index=null

Hjorth, L., Burgess, J., \& Richardson, I. (2012). Studying the mobile: Locating the field. In Studying Mobile Media: Cultural Technologies, Mobile Communication, and the iPhone (pp. 1-7). Routledge.

https://researchrepository.rmit.edu.au/discovery/fulldisplay/alma9921858622201341/61RMIT_INST:Resea rchRepository

Document Version: Published Version

Repository homepage: https://researchrepository.rmit.edu.au

(c) 2012 Taylor \& Francis

Downloaded On 2023/04/26 21:58:24 +1000

Please do not remove this page 
Thank you for downloading this document from the RMIT Research Repository.

The RMIT Research Repository is an open access database showcasing the research outputs of RMIT University researchers.

RMIT Research Repository: http://researchbank.rmit.edu.au/

\section{Citation:}

Hjorth, L, Burgess, J and Richardson, I 2012, 'Studying the mobile: Locating the field' in L. Hjorth, J. Burgess \& I. Richardson (ed.) Studying Mobile Media: Cultural Technologies, Mobile Communication, and the iPhone, Routledge, New York, pp. 1-7.

See this record in the RMIT Research Repository at:

http://researchbank.rmit.edu.au/view/rmit:22203

Version: Published Version

Copyright Statement: (c) 2012 Taylor \& Francis

Link to Published Version:

http://trove.nla.gov.au/work/156597217 


\title{
1 Studying the Mobile \\ Locating the Field
}

\author{
Larissa Hiorth, Jean Burgess, \\ and Ingrid Richardson
}

\section{INTRODUCTION}

Over the past decade we have witnessed many transformations in the field of mobile communication as it moves unevenly into the smartphone era. This relatively short period has seen the emergence of a large body of literature that has addressed the multi-modal nature of, and need for interdisciplinary approaches to, mobile communication. ${ }^{1}$ While much of this earlier work aimed to provide critical analyses of communicative practices surrounding mobile phone use, more recent texts have turned their attention to the mobile as an online, networked media device for games, video, music, and various other forms of everyday creativity. The smartphone's convergence of social, geolocative, and mobile media presents new challenges for how we study the increasingly mobile and interconnected fields of media production, distribution, and consumption. As an object of study, mobile media has expanded to encompass much more than just mobile communication-in turn attracting interest from internet studies, games studies, new media studies, and art, each discipline approaching mobile media devices from particular conceptual and methodological perspectives. So although mobile media scholarship has begun to grow, ${ }^{2}$ it is by no means a coherent field of scholarship, and there are still many areas in need of elaboration and differentiation. What constitutes studying mobile media? For example, at what point is the study of mobile media the preoccupation of internet or game researchers? In its migration across a variety of areas, does the mobile media field have distinct characteristics? As the epitome of ubiquity, mobile media in an age of smartphones requires that we not only attempt to articulate the field but also to more systematically understand its various dimensions - the technical, cultural, social, political, and economic.

The iPhone represents a distinctive moment, both in the very short history of mobile media and in the much longer history of cultural technologies. Like the Walkman three decades earlier, ${ }^{3}$ it marks a historical conjuncture in which notions about identity, individualism, lifestyle, and sociality-and their relationship to technology and media practice-require rearticulation. Studying Mobile Media explores not only the iPhone's particular characteristics, uses, and "affects," but also how the iPhone "moment" functions 


\section{Larissa Hiorth, Jean Burgess, and Ingrid Richardson}

as a barometer for broader patterns of change, as well as the debates and controversies associated with them. By considering the iPhone "moment," Studying Mobile Media considers the number of convergent trajectories in the evolution of digital and mobile culture, and their implications for future scholarship. Through the lens of the iPhone-as a symbol, culture, and set of material practices around contemporary convergent mobile media, as well as a particular form of proprietary platform-the chapters included in this book explore some of the most productive available theoretical and methodological approaches for grasping media practice, consumer culture, and networked communication in the twenty-first century.

As a project, Studying Mobile Media took as a starting point Paul du Gay et al.'s "circuits of culture" approach, introduced in Doing Cultural Studies, which invited researchers to map the dynamics of culture-described by the core categories of consumption, production, regulation, representation and identity-as they co-influenced one another to produce the meanings of a particular cultural object (in that case, the Sony Walkman). ${ }^{4}$ While the Sony Walkman case study itself is now decades old, the ongoing significance of this approach was captured by Gerard Goggin's more recent reinterpretation of it in Cell Phone Culture. ${ }^{5}$ Doing Cultural Studies used an analysis of a significant technology of the time (the Sony Walkman) for dual purposes: to analyze new forms of media practice (consumption and production), and at the same time to consolidate and communicate the theoretical and methodological approaches of what was still an emerging discipline (Cultural Studies) for the benefit of students and researchers.

The ongoing relevance of Doing Cultural Studies beyond the "moment" of the Sony Walkman was that it captured the zeitgeist of cultural analysis in the 1990s and provided a benchmark for Cultural Studies research beyond that moment. Studying Mobile Media has similar aims: to use a single but highly complex cultural object (the iPhone) as a starting point, and to make available to readers a range of approaches and methods that may be useful in making sense of the contemporary proliferation of mobile media, social media, and user-created content; as well as contemporary trends in technological, cultural, and industrial convergence; and their implications for media, culture, and society. Through locating social mobile media within a diversity of cultural and industry contexts, Studying Mobile Media examines the ways in which technologies are both taken up and rejected by users. Indeed, Studying Mobile Media is as much interested in "discontinuous innovation" (products and applications that fail) as exploring the long-term effects of usage once the "honeymoon" period of new acquisition is over and the technology becomes integrated into users' everyday lives.

\section{THE ARCHITECTURE OF THIS BOOK}

Studying Mobile Media is not a simple celebration of the iPhone; rather, throughout the book the iPhone is deployed as a means of critically a nalyzing 
contemporary situated media practice-from social media and networked mobile media to creative industries such as the games industry. While the chapters do address the particularities of the iPhone-especially in terms of its photographic, game and geolocative media applications or "apps"-we also uncover some salient issues about the role of media in shaping, and being shaped by, locality, sociality and intimacy more broadly. Building upon the work conducted in mobile communication studies, Studying Mobile Media considers new forms of expression emerging from photographic applications, location-based services (LBSs), along with the associated phenomena of usercreated content and social media, and the dynamics of convergence. The first section of the book provides both macro and micro perspectives on the iPhone as a cultural, technological and historical moment. Goggin's chapter provides an insightful analysis of the Apple Inc. machine in relation to the field of communication studies; Jean Burgess reimagines the open/closed platform debate in terms of the iPhone's position within the broader history of cultural technologies; the following two chapters offer cultural case studies of the iPhone as a moment in user practice: in China (Hjorth, Wilken, and $\mathrm{Gu})$ and in Korea (Lee).

In Goggin's chapter, the iPhone is contextualized within broader mobile communication debates. Here, Goggin succinctly identifies not only how studying the iPhone can inform wider debates around mobile communication but also how the iPhone needs to be situated within such media ecologies. By addressing four key scholars in the area-James Katz, Christian Licoppe, Manuel Castells and Leopoldina Fortunati-Goggin provides a media compass with which to locate the iPhone. Contextualizing and situating the iPhone is also the agenda in Burgess's chapter; however, for Burgess, the iPhone needs to be understood as a moment in the longer and highly contested history of computer culture, and in particular, the way that user agency has been framed in the design and representation of personal computer technology. Burgess traces the shifts in Apple's corporate ethos, design and marketing practices from the late 1970s onward, arguing that earlier tensions between a "hacker" ethos and a market-driven populist one have resolved into a situation where highly usable but "closed" or "tethered" technologies—especially the iPhone-paradoxically provide the capacity for, rather than limiting, "cultural generativity."

Having situated the iPhone within two of its most important historical contexts, the book's next chapters mark the shift toward understanding the iPhone as a site of socio-cultural practice. Larissa Hjorth, Rowan Wilken, and Kay Gu consider the iPhone as a portal to geolocative media (geomedia) for young people in Shanghai, representing a particular "moment" within Chinese technoculture. Beyond the stories of Apple shanzhai (copy culture) stores, the iPhone presents a particular inroad into LBSs such as Jie Pang; this media practice is the preoccupation of a particular generation-in China they are called the ba ling hou (born between 1980 and 1989). As Hjorth et al. suggest, the deployment of Jie Pang through the iPhone reinforces culturally specific notions of social capital in the form of 
guanxi. From the Chinese context we migrate to Korea; in Dong-Hoo Lee's chapter, South Korean technoculture is identified as a dominant player in new media technologies through companies such as Samsung and LG. But as Lee notes, the introduction of the iPhone within the Korean context was quickly dubbed the "iPhone shock." In order to gain insight beyond the effects of this "shock," Lee firstly outlines the rise of mobile media communications in light of the smartphone spectacle and then moves onto a case study of Korean twenty-something iPhone users to gain a sense of the lived experience of mobile media practices in South Korea.

As a platform and phenomenon, we see how iPhone media practicesymbolized by its apps-provides numerous media cultures that both rehearse and extend practices across visual cultures, gaming and augmented reality. In "Part II: iPhone as a Platform and Phenomenon," we move through five very different and yet complementary case studies across photography, geomedia and games. In Palmer's, Chesher's and Verhoeff's discussions of iPhone photography, we see how apps both reinforce and depart from previous image practices. Camera phone practices amplify the local, highlighting the divergent ways in which public, private and the personal-especially converging around intimacy and intimate publics-are being reconfigured. ${ }^{6}$ As Amparo Lasén and Edgar Gømez have observed in the case of the networked capacities of camera phones through online communities like Flickr, divides between public and private are undergoing significant change. ${ }^{7}$ For Scott McQuire, the reconfiguration of public and private is part of the "new ways of conceptualizing the space and time of social experience and agency in a context in which the older boundaries of both territory and media are in a flux." ${ }^{\prime}$

These transformations are reflected in Palmer's discussion of the iPhone as part of the creative lifestyle and the questions this brings to bear on professional photography. In the first generation of camera phone studies, debates revolved around the erosion between a mateur and professional users, especially concerning photo-journalism ${ }^{9}$ and the way in which it interwove intimacy and co-presence ${ }^{10}$ with banality. ${ }^{11}$ The issue of a (networked) context, as it informed (vernacular) content, was key to these studies. ${ }^{12}$ In light of the increased sophistication of the lens and editing suites, along with networked contexts such as Flickr, ${ }^{13}$ Palmer considers whether one can talk about iPhone photography as a visual arts practice.

In Chesher's chapter, the context of iPhone photography is situated within a philosophical, rather than visual art, context. Moving beyond the first generation of camera phone studies that, according to Mizuko Ito and Daisuke Okabe, ${ }^{14}$ was symbolized by the logic of ambient co-present intimacy in the form of three "s": sharing, storing and saving, Chesher argues that iPhone apps "transform, translate and transmit" images. Picking up on earlier discussions about the haunting of the analogue within digital photography (i.e., in programs such as Final Cut Pro, Adobe Photoshop), Chesher argues that iPhone apps further augment and simulate the 
nostalgic image. Drawing from Félix Guattari's essay "Machinic heterogenesis," Chesher philosophically probes the limits and possibilities-in the form of specific Universes of reference-of iPhone photography especially in terms of geomedia (location-based services). Nanna Verhoeff takes this philosophical analysis further by considering case studies of geomedia and its impact upon situated and augmented reality. Unlike Chesher's chapter that focuses squarely on the iPhone, Verhoeff's discussion oscillates between the generalities of smartphone capabilities and the specificity of the iPhone, demonstrating the liminalities of the iPhone as a theoretical object. Drawing on structuralism, Verhoeff investigates the way in which iPhone navigation can be viewed as "a performative practice in mobile and interactive augmented reality tours."

Verhoeff's robust discussion of augmented reality within current mobile media practices provides a segue into the next chapter on mobile gaming and the iPhone. While the burgeoning of mobile games is not exclusive to the iPhone, the device does lend itself to particular kinds of game play and game cultures that are different from other handheld or haptic game consoles. ${ }^{15}$ In "Touching the Screen," Ingrid Richardson begins with a discussion of the micro- and macro-corporeal effects of touchscreen smart phones and the various embodiment relations specific to mobile gaming on such devices. She then turns to the particular affordances or "socio-somatics" of the iPhone as a game interface and offers a comparative analysis of location-based and casual iPhone games with respect to their distinct modalities of place, presence and being-in-the-world.

In the final section of the book, the discussion moves away from representation, consumption and practice toward the iPhone's conditions of production and its attendant forms of labor. Continuing the theme of iPhone games, John Banks turns our attention toward the specific model the iPhone's platform provides for industry development. By focusing upon iPhone games developer, HalfBrick, Banks considers the limits of innovation in relation to the iPhone as a development platform, and how this is both enabling and shaping practices within the games, soft ware and content industries. In his vivid portrayal of the inhumane conditions surrounding iPhone production, Jack Linchuan Qiu considers the ugly side of the iPhone phenomenon. In "Network Labor" we are told about the worker suicides and the walled community of Foxconn, and finally left to reflect upon the cruel complicity involved in iPhone consumption. Qiu's moving depiction of Chinese workers in iPod City is followed by Hjorth's case study of female iPhone users in Australia in which she considers whether we can talk of an iPhone "affect." Consisting of both working mothers and non-mother users, Hjorth considers how the iPhone participates in the relationship between public and private, work and leisure boundaries. Through this case study, Hjorth asks whether the iPhone informs particular practices of personalization. Following on from Hjorth is Kate Crawford's "Four Ways of Listening with an iPhone," which discusses specific "vectors of listening" 


\section{Larissa Hjorth, Jean Burgess, and Ingrid Richardson}

that traverse the iPhone and its users, along with other networked devices and media forms. Crawford identifies and critically examines a number of iPhone apps that demand particular kinds of individual and collective labor, including those that alter the way we engage with both sound and music in our immediate environment, allow us to perpetually listen-in to social networks and newsfeeds, enable "biometric listening" by monitoring one's mood, health and productivity, and finally "eavesdrop" on us by tracking and storing our location data. From the labors of listening, the final chapter of this collection provides us with a narrative of iPhone acquisition within an organization. Drawing from a case study of an art and design school, Ilpo Koskinen considers some of the paradoxes around professional creativities working within the university and the limits of the institution in affording space for those personalization practices. Universities, on the one hand, are big, often unwieldy organizations in which changes take much time and procedure. And yet, on the other hand, if a university prides itself on innovation-especially around new media technologies-it needs to be able to administer and implement new technologies quickly. Moreover, as universities increasingly become corporatized, their employees often have difficulties negotiating personal and work media.

Taking the iPhone both as a central object of study and as a departure point, Studying Mobile Media considers a range of socio-cultural and industrial factors informing the rise of new media practices within the context of networked and user-created content environments. In providing a critical snapshot of these factors and practices, Studying Mobile Media moves beyond the current dominance of bifurcated conceptual models that imagine users as either "empowered" or "exploited." By investigating the emerging creative practices associated with mobile media-practices that involve emotion, affect and sociality as well as new forms of storytelling and collaboration-Studying Mobile Media moves these debates forward. We hope that this consideration of the iPhone as a key technical and cultural "moment" will provide the impetus for deeper cross-disciplinary approaches to broader trends and trajectories within media culture, effectively going beyond existing studies of mobile media and communication.

\section{ACKNOWLEDGEMENTS}

We would like to thank the Australian Research Council's Cultural Research Network (CRN) for their support of an iPhone workshop in June 2009 at Queensland University of Technology. Also special thanks goes to CRN director, Professor Graeme Turner.

\section{NOTES}

1. James Katz, ed., Handbook of Mobile Communication Studies (Cambridge, MA: MIT Press, 2009); James Katz and Mark Aakhus, eds., Perpetual Contact: Mobile Communication, Private Talk, Public Performance (Cambridge: Cambridge University Press, 2002); Peter Glotz and Stefan Bertschi, eds., 
Thumb Culture: Social Trends and Mobile Phone Use (Bielefeld: Transcript Verlag, 2005); Manuel Castells, Mireia Fernández-Ardevol, Jack Linchuan Qiu and Araba Sey, Mobile Communication and Society: A Global Perspective (Cambridge, MA: MIT Press, 2007); Richard Ling and Peter Pedersen, eds., Mobile Communication: Re-negotiation of the Social Sphere (London: Springer-Verlag, 2005); Daniel Miller and Heather Horst, Cell Phone (Oxford and New York: Berg, 2005); Gerard Goggin, Cell Phone Culture: Mobile Technology in Everyday Life (London: Routledge, 2006); Mizuko Ito, Daisuke Okabe and Misa Matsuda, eds., Personal, Portable, Pedestrian: Mobile Phones in Japanese Life (Cambridge, MA: MIT Press, 2005); Richard Ling and Jonathan Donner, Mobile Phones and Mobile Communication (London: Polity Press, 2009).

2. Gerard Goggin and Larissa Hjorth, "Editorial: waiting to participate: emerging modes of digital storytelling, engagement and online communities," Communication, Policy and Culture 42(2), 2009: 1-5; Larissa Hjorth, Mobile Media in the Asia-Pacific: Gender and the Art of being Mobile (London: Routledge, 2009); Gerard Goggin, Global Mobile Media (London: Routledge, 2011).

3. Paul du Gay, Stuart Hall, Linda Janes, Hugh Mackay and Keith Negus, Doing Cultural Studies: The Story of the Sony Walkman, Culture, Media and Identities (London: Sage, 1997).

4. Ibid.

5. Goggin, 2006.

6. Larissa Hjorth, "Engagement rings: a cross-cultural analysis of camera phone genres, modes of sharing and digital storytelling," The Future of Digital Media Culture: 7 th International Digital Arts and Culture (DAC) Conference, 15-18 September 2007, Perth, Australia http://www.beap.org/dac

7. Amparo Lasén and Edgar Gómez-Cruz, "Digital photography and picture sharing: redefining the public/private divide," Knowledge, Technology and Politics 22, 2009: 205-215.

8. Scott McQuire, The Media City. Media, Architecture and Urban Space (London: Sage, 2008), 20.

9. Gerard Goggin, "Calling the shots," Sydney Morning Herald/Fairfax Digital, 2 July 2005, http://smh.com.au/articles/2005/06/30/1119724747968. html (accessed 6 July 2005); Larissa Hjorth, "Snapshots," Cultural Space and the Public Sphere in Asia, hosted by Asia's Futures Initiative, 15-16 March 2006, Seoul; Larissa Hjorth, "Snapshots of almost contact: case study on South Korea," Continuum 21(2) 2007: 227-238.

10. Mizuko Ito and Daisuke Okabe, "Intimate Visual Co-Presence," presented at UbiComp, 2005 September 11-14, Takanawa Prince Iotel, Tokyo, Japan, http://www.itofisher.com/mito/ (accessed 10 December 2005).

11. Koskinen, 2007.

12. Ito and Okabe, op. cit.

13. Søren Mørk Petersen, "Common banality: the affective character of photo sharing, everyday life and produsage cultures," unpublished Ph.D. (Copenhagen, Denmark: IT University of Copenhagen, 2009).

14. Ito and Okabe, op. cit.

15. Larissa Hjorth and Ingrid Richardson, "The waiting game: complicating notions of (tele)presence and gendered distraction in casual mobile gaming," in Hajo Greif, Larissa Hjorth, Amparo Lasén and Claire Lobet-Maris, eds., Cultures of Participation (New York: Peter Lang: 2010), 111-125 